\title{
Pertumbuhan Kepiting Bakau Scylla olivacea dengan Rasio Jantan-Betina berbeda yang dipelihara pada Kawasan Mangrove
}

\section{Growth of Varied Ratio of Male-Female Mud Crab Scylla olivacea Maintaned in Mangrove Area}

\author{
Muhammad Y. Karim ${ }^{1 *}$, Hasni Y. Azis ${ }^{2} \&$ Muslimin $^{3}$ \\ 1,2 Jurusan Perikanan, FIKP UNHAS, Makassar \\ JI. Perintis Kemerdekaan Km.10, Tamanlarea Indah Makassar 90245 \\ ${ }^{3}$ Politeknik Pertanian Negeri Pangkep \\ Jl. Poros Makassar-Parepare Km. 83 Mandalle, Pankep, Kabupaten Pangkajene dan Kepulauan 90761 \\ *Penulis untuk korespondensi, e-mail: yusri_karim@yahoo.com
}

\begin{abstract}
Abstrak
Budidaya kepiting bakau untuk penggemukan potensial untuk dikembangkan pada kawasan mangrove. Penelitian ini bertujuan untuk menentukan rasio jantan dan betina yang tepat pada budidaya penggemukan kepiting bakau (Scylla olivacea) yang dipelihara pada kawasan mangrove. Penelitian dilaksanakan di kawasan mangrove Kabupaten Pangkep, Propinsi Sulawesi Selatan. Hewan uji yang digunakan adalah kepiting bakau (S. olivacea) jantan dan betina berukuran bobot $250 \pm 10 \mathrm{~g}$ yang ditebar dengan kepadatan $10 \mathrm{ekor} / \mathrm{kurungan}$. Wadah yang digunakan adalah kurungan bambu berukuran panjang, lebar, dan tinggi masing-masing 1,0 x 1,0 $x 1,0 \mathrm{~m}^{3}$ yang ditempatkan di kawasan mangrove. Pakan yang digunakan adalah ikan-ikan rucah dosis $10 \%$ dari biomassa kepiting dengan frekuensi pemberian pakan 2 kali sehari yakni pagi dan sore hari sebesar $30 \%$ dan $70 \%$. Penelitian menggunakan rancangan acak lengkap (RAL) yang terdiri atas 4 perlakuan dan 3 ulangan. Sebagai perlakuan adalah rasio kepiting jantan dan betina, yaitu: 7:3, 6:4, 5:5, 4:6 dan 3:7 ekor/kurungan. Hasil analisis ragam memperlihatkan bahwa rasio jantan dan betina tidak berpengaruh nyata $(p>0,05)$ pada sintasan kepiting, akan tetapi berpengaruh sangat nyata $(p<0,01)$ pada pertumbuhan mutlak dan laju pertumbuhan harian kepiting bakau (S. olivacea). Sintasan yang dihasilkan berkisar $93,33-100 \%$, pertumbuhan mutlak dan laju pertumbuhan harian kepiting tertinggi dihasilkan pada rasio jantan dan betina 7:3 dan 6:4 ekor/kurungan yakni $56,99 \mathrm{~g}$ dan $1,35 \% ; 56,25 \mathrm{~g}$ dan 1,36\%/hari sedangkan terendah pada rasio $3: 7$ ekor/kurungan yakni $28,97 \mathrm{~g}$ dan 0,73\%/hari.
\end{abstract}

Kata kunci: Kepiting, pertumbuhan, rasio jantan dan betina, sintasan

\begin{abstract}
Mudcrab fattening is potential to develop in mangrove areas. The aim of the present study was to determine the best ratio of male and female in fattening of mud crab in the mangrove area. Research was conducted in the mangrove areas of Pangkep Regency, South Sulawesi Province. Test animals used were mud crab $S$. olivacea male and female measuring weight of $250 \pm 10 \mathrm{~g}$ and were stocked at a density of 10 animals/cage. The bamboo cages measuring length, width, and height of $1.0 \times 1.0 \times 1.0 \mathrm{~m}^{3}$ were placed in the mangrove areas. Feed used was trash fish at $10 \%$ of the biomass with the feeding frequency of two times a day ie morning $(30 \%)$ and afternoon (70\%). The study used a completely randomized design (CRD) consisting of 4 treatments and 3 replications. The ratio of male and female crabs were $7: 3 ; 6: 4 ; 5: 5 ; 4: 6$ and $3: 7$ crabs/cage, respectively. Results of analysis of variance showed that the treatment with the different ratio of male and female was not significant $(p>0.05)$ on the survival rate of crab, but was highly significant $(p<0.01)$ on the absolute and daily growth rate. The resulting survival rate ranges from 93.33 to $100 \%$, absolute growth and the highest daily growth rate of crabs produced at a ratio of males and females (7:3) and (6:4) crabs/cage ie: 56.99 and $1.35 ; 56.25 \mathrm{~g}$ and $1.36 \% /$ day, while the lowest was in the ratio (3:7) crabs/cage ie: $28.97 \mathrm{~g}$ and $0.73 \% /$ day.
\end{abstract}

Keywords: Crab, growth, ratio of male-female, survival

\section{Pengantar}

Mangrove merupakan ekosistem khas daerah pantai yang memiliki produktivitas tinggi dan berperan sebagai fungsi fisik, ekologis dan ekonomis. Adanya interaksi diantara komponen-komponen ekosistem mangrove menjadikan ekosistem tersebut sebagai habitat yang baik bagi berbagai jenis biota (Ong \& Gong, 2013; Lee et al., 2014). Selain kondisi pasang surut dan kesuburannya yang mendukung, Mangrove 
memiliki potensi untuk dikembangkan menjadi kawasan pertambakan. Kenyataan tersebut sering kita jumpai dimana lahan mangrove telah dikonversi menjadi tambak.

Kegiatan pengalihan fungsi natural mangrove menjadi kawasan pertambakan (fungsi ekonomi) seringkali tidak memperhatikan aspek kelestarian dan kelayakannya. Akibatnya terjadi penurunan kualitas lingkungan sehingga terancamnya berbagai jenis fauna penghuni mangrove. Dengan mempertimbangkan berbagai fungsi, maka upaya mengkonversi mangrove menjadi pertambakan harus dilakukan secara rasional dengan berwawasan lingkungan. Oleh sebab itu, perlu diterapkan suatu sistem yang dapat menjamin kedua kepentingan tersebut, salah satunya adalah sistem tumpang sari atau silvofishery yaitu suatu kegiatan budidaya pada daerah mangrove. Hal tersebut perlu dilakukan sebagai salah satu langkah tepat dalam menjaga kelestarian mangrove yang secara ekologis berperandalam menjaga habitat pesisir dan menghasilkan produk perikanan bernilai ekonomis penting.

Berbagai jenis biota ekonomis yang dapat dibudidayakan di daerah mangrove salah satunya adalah kepiting bakau (Scylla sp.) (Okpiliya et al., 2013). Kepiting bakau merupakan salah satu komoditas perikanan bernilai ekonomis penting yang banyak disukai konsumen baik di pasaran dalam negeri maupun luar negeri (Mirera \& Mtile, 2009; Peterson \& Mann, 2011; Shelley \& Lovatelli, 2011; Karim, 2013; Mirera \& Moksnes, 2014). Jenis kepiting ini telah dibudidayakan secara komersial di beberapa negara tropis termasuk Indonesia (Shelley, 2008; Karim, 2013). Budidaya kepiting bakau memiliki prospek yang cukup baik, pangsa pasar terbuka luas dengan nilai ekonomis yang tinggi. Secara umum kegiatan budidaya kepiting bakau terdiri atas: pembesaran, penggemukan, produksi kepiting bertelur, dan produksi kepiting lunak (soft shell crab). Penggemukan kepiting bakau yaitu suatu usaha untuk menambah bobot kepiting yang semula masih kurus menjadi kepiting yang gemuk (Mahato, 2008). Pemeliharaan kepiting bakau beberapa hari mengakibatkan terjadinya perkembangan secara fisiologi sehingga bobot tubuh bertambah (Tahya, 2016; Tahya et al., 2016; Karim, et al., 2016). Usaha penggemukan kepiting potensial untuk dikembangan karena hanya memerlukan modal kecil, waktu pemeliharaan singkat, dan teknologi sederhana. Dalam budidayanya berbagai faktor yang perlu diperhatikan salah satunya adalah padat penebaran dengan rasio antara jantan dan betina. Oleh sebab itu, guna menghasilkan kepiting bakau dengan sintasan dan pertumbuhan yang tinggi diperlukan padat tebar dangan rasio jantan dan betina yang tepat.
Penelitian ini bertujuan untuk menentukan rasio jantan dan betina yang tepat pada budidaya penggemukan kepiting bakau yang dipelihara pada kawasan mangrove. Hasil penelitian diharapkan dapat menjadi salah satu informasi tentang pengaplikasian budidaya penggemukan kepiting bakau yang dipelihara pada kawasan mangrove.

\section{Bahan dan Metode}

\section{Bahan}

Hewan uji yang digunakan adalah kepiting bakau (Scylla olivacea) jantan dan betina kurus berukuran bobot $250 \pm 10 \mathrm{~g}$ yang ditebar dengan kepadatan 10 ekor/kurungan. Kepiting tersebut didatangkan dari pengumpul kepiting di Desa Pallime, Kecamatan Cenrana, Kabupaten Bone, Sulawesi Selatan.

Wadah yang digunakan adalah kurungan yang terbuat dari bambu berukuran panjang, lebar, dan tinggi masing-masing 1,0 x 1,0 x 1,0 $\mathrm{m}^{3}$. Kurungan tersebut ditempatkan di kawasan mangrove. Pada bagian luar kurungan dilapisi waring yang bertujuan untuk melindungi kurungan dari sampah dan kotoran yang terbawa oleh ombak.

Pakan yang digunakan adalah ikan-ikan rucah yang diperoleh di sekitar lokasi penelitian. Dosis pakan yang diberikan adalah $10 \%$ dari biomassa perhari. Frekuensi pemberian pakan dilakukan dua kali sehari yakni pada pagi hari (pukul 06.30) sebanyak $30 \%$ dan sore hari (pukul 17.30) 70\% dari total pakan yang diberikan.

\section{Metode}

Penelitian ini dirancang dengan menggunakan rancangan acak lengkap (RAL dengan 5 perlakuan dan setiap perlakuan masing-masing mempunyai 3 ulangan). Dengan demikian, penelitian ini terdiri atas 15 satuan percobaan. Kelima perlakuan yang dicobakan adalah perbandingan rasio kepiting jantan dan betina per kurungan, yaitu;
1. $7: 3$
2. $6: 4$
3. $5: 5$
4. $4: 6$
5. $3: 7$

Parameter yang diamati pada penelitian ini adalah sintasan dan pertumbuhan kepiting bakau. Sintasan dihitung dengan menggunakan rumus:

$\mathrm{SR}=\left(\mathrm{N}_{\mathrm{t}} / \mathrm{N}_{\mathrm{o}}\right) \times 100$

dimana SR adalah sintasan kepiting (\%), $\mathrm{N}_{\mathrm{o}}$ adalah jumlah kepiting pada awal penelitian (ekor), $N_{t}$ adalah jumlah kepiting yang hidup pada akhir penelitian (\%) (Huynh \& Fotedar, 2004). 
Pertumbuhan mutlak kepiting dihitung dengan menggunakan rumus $P M=B_{t}-B_{0}$, dimanaPM adalah pertumbuhan mutlak $(\mathrm{g}), \mathrm{B}_{\mathrm{o}}$ adalah bobot rata-rata kepiting pada awal penelitian $(\mathrm{g}), \mathrm{B}_{\mathrm{t}}$ adalah bobot rata-rata kepiting pada akhir penelitian.

Laju pertumbuhan harian kepiting dihitung dengan menggunakan rumus $S G R=100 \times\left(\ln W_{t}-\ln W_{o}\right) / t$, dimana: SGR adalah laju pertumbuhan harian (\%/ hari), $W_{0}$ adalah bobot rata-rata kepiting pada awal penelitian (g), $W_{t}$ adalah bobot rata-rata kepiting pada akhir penelitian ( $\mathrm{g}$ ), $\mathrm{t}$ adalah lama pemeliharaan (hari) (Changbo et al., 2004).

Sebagai data penunjang dilakukan pengukuran beberapa parameter fisika kimia lingkungan pemeliharaan meliputi suhu, salinitas, $\mathrm{pH}$, oksigen terlarut, amoniak, dan nitrit. Pengukuran suhu, salinitas, $\mathrm{pH}$, dan oksigen terlarut dilakukan setiap hari sebanyak 2 kali, yaitu pagi dan sore hari. Adapun kadar amoniak dan nitrit diukur 3 kali selama penelitian yaitu pada awal, pertengahan, dan akhir penelitian.

Data yang diperoleh dianalisis dengan menggunakan sidik ragam (ANOVA). Uji W-Tuckey digunakan untuk membandingkan perbedaan antara perlakuan (Steel \& Torrie, 1993). Sebagai alat bantu untuk uji statistik tersebut digunakan paket program SPSS versi 22.0. Adapun data kualitas air yang diperoleh dianalisis secara deskriptif berdasarkan kelayakan hidup kepiting bakau.

\section{Hasil dan Pembahasan}

Hasil

\section{Sintasan}

Rata-rata sintasan kepiting bakau yang dipelihara dengan rasio jantan dan betina pada kawasan mangrove disajikan pada Tabel 1.

Tabel 1. Rata-rata sintasan kepiting bakau yang dipelihara dengan rasio jantan dan betina pada kawasan mangrove.

\begin{tabular}{cr}
\hline $\begin{array}{c}\text { Rasio Jantan dan Betina } \\
\text { (ekor/kurungan) }\end{array}$ & Sintasan (\%) \\
\hline $7: 3$ & $96,67 \pm 5,77$ \\
$6: 4$ & $96,67 \pm 5,77$ \\
$5: 5$ & $93,33 \pm 5,77$ \\
$4: 6$ & $100,00 \pm 0,00$ \\
$3: 7$ & $100,00 \pm 0,00$ \\
\hline
\end{tabular}

Keterangan: tidak berbeda nyata antar perlakuan pada taraf $5 \%(p>0,05)$.

Hasil analisis ragam menunjukkan bahwa rasio kelamin jantan dan betina berbeda tidak berpengaruh nyata $(p>0,05)$ pada sintasan kepiting bakau yang untuk penggemukan dipelihara pada kawasan mangrove.

\section{Pertumbuhan}

Rata-rata Pertumbuhan kepiting bakau yang dipelihara dengan rasio jantan dan betina berbeda pada kawasan mangrove disajikan pada Tabel 2 .

Tabel 2. Rata-rata pertumbuhan kepiting bakau yang dipelihara dengan rasio jantan dan betina berbeda pada kawasan mangrove.

\begin{tabular}{ccc}
\hline $\begin{array}{c}\text { Rasio Jantan } \\
\text { dan Betina } \\
\text { (ekor/kurungan) }\end{array}$ & $\begin{array}{c}\text { Pertumbuhan } \\
\text { Mutlak } \\
(\mathrm{g})\end{array}$ & $\begin{array}{c}\text { Laju Pertumbu- } \\
\text { han Harian } \\
(\% / \text { hari })\end{array}$ \\
\hline $7: 3$ & $56,99 \pm 1,55^{\mathrm{a}}$ & $1,36 \pm 0,03^{\mathrm{a}}$ \\
$6: 4$ & $56,25 \pm 0,28^{\mathrm{a}}$ & $1,35 \pm 0,01^{\mathrm{a}}$ \\
$5: 5$ & $40,67 \pm 0,33^{\mathrm{b}}$ & $1,00 \pm 0,01^{\mathrm{b}}$ \\
$4: 6$ & $31,13 \pm 0,67^{\mathrm{c}}$ & $0,78 \pm 0,02^{\mathrm{c}}$ \\
$3: 7$ & $28,97 \pm 0,72^{\mathrm{c}}$ & $0,73 \pm 0,02^{\mathrm{c}}$ \\
\hline
\end{tabular}

Keterangan: huruf yang berbeda pada kolom yang sama menunjukkan perbedaan yang nyata antar perlakuan pada taraf $5 \%(p<0,05)$.

Hasil analisis ragam menunjukkan bahwa rasio kelamin jantan dan betina berpengaruh sangat nyata $(p<0,01)$ pada pertumbuhan mutlak dan laju pertumbuhan harian kepiting bakau yang dipelihara untuk penggemukan pada kawasan mangrove.

\section{Fisika Kimia Air}

Selama penelitian berlangsung dilakukan pengukuran beberapa parameter fisika kimia air lingkungan pemeliharaan kepiting bakau yang meliputi suhu, salinitas, $\mathrm{pH}$, oksigen terlarut, amoniak, nitrit, dan kekeruhan disajikan pada Tabel 3.

Tabel 3. Hasil pengukuran fisika kimia air lingkungan pemeliharaan kepiting bakau.

\begin{tabular}{lc}
\hline \multicolumn{1}{c}{ Parameter } & Nilai Kisaran \\
\hline Suhu $\left({ }^{\circ} \mathrm{C}\right)$ & $25-29$ \\
Salinitas (ppt) & $23-28$ \\
$\mathrm{pH}$ & $7,23-7,52$ \\
DO (ppm) & $3,65-5,01$ \\
Amoniak (ppm) & $0,03-0,09$ \\
Nitrit (ppm) & $0,30-0,34$ \\
\hline
\end{tabular}

Pembahasan

Berdasarkan hasil penelitian, budidaya penggemukan kepiting bakau pada kawasan mangrove yang dipelihara dengan rasio jantan dan betina berbeda tidak memberikan pengaruh nyata terhadap sintasan. $\mathrm{Hal}$ ini menggambarkan bahwa rasio kelamin jantan 
dan betina yang berbeda pada penggemukan kepiting bakau menghasilkan sintasan yang sama. Nilai sintasan yang dihasilkan tinggi yakni berkisar $93,33-100 \%$. Sintasan yang tinggi ini disebabkan rasio jantan dan betina yang masih layak dan tingkat kecukupan pakan sehingga mendukung sintasan kepiting bakau secara maksimal. Sintasan lebih tinggi yang ditemukan pada metode budidaya dasar terhadap kepiting bakau pernah dilaporkan berkisar antara $80-100 \%$ (Sagala et al.,2013).

Tabel 2 menampilkan bahwa pertumbuhan mutlak dan laju pertumbuhan harian pada budidaya penggemukan kepiting bakau yang dipelihara pada kawasan mangrove tertinggi dihasilkan pada rasio kepiting jantan dan betina 7:3 dan 6:4 ekor/ kurungan sedangkan terendah pada rasio 4:6 dan 3:7 ekor/kurungan. Hal ini menggambarkan bahwa untuk budidaya penggemukan kepiting bakau yang dipelihara pada kawasan mangrove dengan rasio kepiting jantan dan betina kepadatan 10 ekor/ kurungan sebaiknya dipelihara dengan rasio 6-7 jantan dan betina 3-4 ekor/kurungan. Tingginya pertumbuhan mutlak dan laju pertumbuhan harian kepiting bakau yang dipelihara pada kawasan mangrove dengan rasio jantan dan betina $7: 3$ dan 6:4 ekor/ kurungan merupakan rasio yang terbaik. Pada kondisi tersebut jumlah kepiting jantan lebih dominan dibandingkan kepiting betina.

Kepiting bakau jantan lebih agresif dalam hal pergerakan dan termasuk pengambilan makanan dibandingkan kepiting bakau betina. Secara fisiologi kepiting betina lebih banyak membutuhkan energi baik persiapan untuk molting (pertumbuhan) maupun untuk pertumbuhan sel telur (gonad) sehingga energi yang dibutuhkan semakin tinggi, terlebih lagi jika dipelihara dalam kurungan yang membatasi aktivitas gerak. Dengan demikian porsi energi untuk pertumbuhan lebih sedikit. Oleh karenanya, pertambahan bobot tubuh kepiting jantan lebih berat dibandingkan betina (Tahya, 2016). Pertumbuhan hanya dapat terjadi bila terdapat kelebihan energi setelah energi yang dikonsumsi digunakan untuk berbagai aktivitas. Cholik (2005) menyatakan bahwa perbedaan pertumbuhan kepiting bakau dalam budidaya disebabkan oleh pakan, umur, bobot awal, ruang gerak, serta faktor lainnya, contohnya: kepiting yang dipelihara dalam kurungan mengalami pertumbuhan yang berbeda; kepiting jantan menggunakan energinya untuk memelihara tubuh, sementara energi untuk reproduksi lebih kecil dibandingkan kepiting betina.

Pertumbuhan kepiting bakau yang rendah pada rasio kelamin jantan dan betina (4:6), dan (3:7) ekor/kurungan dibanding rasio lainnya disebabkan jumlah kepiting betina lebih sedikit dibandingkan jantan. Kepiting bakau jantan memiliki aktivitas yang besar dibanding kepiting betina, termasuk metabolismenya. Aktivitas kepiting jantan yang lebih aktif didukung oleh mekanisme fisiologi, misalnya kinerja organ yang giat jika dibandingkan betinanya (Tahya et al., 2016; Sunarti et al., 2016). Dengan demikian pertumbuhan kepiting jantan lebih cepat dibandingkan kepiting betina. Menurut Wijaya et al. (2010), kepiting bakau jantan cenderung bersifat agresif dalam mencari makan sehingga energi yangdiperoleh untuk pertumbuhan akan menjadi lebih tinggi. Laju pertumbuhan harian yang diperoleh pada penelitian ini berkisar 0,73-1,36\%/hari. Mirera dan Mtile (2009) mendapatkan laju pertumbuhan kepiting bakau sebesar 1,29\%/hari. Sementara itu Trino et al. (2001) mendapatkan laju pertumbuhan yang tinggi pada pembesaran kepiting bakau sebesar 1,8-1,9\%/ hari dengan lama pemeliharaan 156 hari.

Selama penelitian di lapangan berlangsung, parameter fisika kimia air lingkungan berada pada kondisi yang layak untuk pemeliharaan kepiting bakau. Suhu lingkungan selama penelitian berkisar $25-29^{\circ} \mathrm{C}$, salinitas 23-28 ppt pH 7,23-7,52, oksigen terlarut 3,65-5,01 ppm, amoniak 0,03-0,09 ppm, dan nitrit $0,30-0,34 \mathrm{ppm}$. Kisaran nilai-nilai tersebut layak untuk mendukung kehidupan kepiting bakau. Suhu yang optimum untuk pertumbuhan kepiting bakau berkisar 26-32 ${ }^{\circ} \mathrm{C}$, salinitas berkisar $15-30 \mathrm{ppt}$, $\mathrm{pH}$ berkisar $7,0-8,5$, oksigen terlarut $>$ dari 3 ppm, amoniak $<0,1$ ppm dan nitrit < 0,5 ppm (Christensen et al., 2005; Karim, 2013; Pedapoli \& Ramudu, 2014).

\section{Kesimpulan}

Berdasarkan penelitian ini dapat disimpulkan bahwa budidaya penggemukan kepiting bakau yang dipelihara pola kawasan mangrove dengan rasio jantan dan betina berbeda menghasilkan sintasan yang sama, pertumbuhan mutlak dan laju pertumbuhan harian tertinggi dihasilkan pada rasio 7:3 dan 6:4/kurungan sedangkan terendah pada 4:6 dan $3: 7 /$ kurungan.

\section{Saran}

Dalam budidaya penggemukan kepiting bakau yang dipelihara pada kawasan mangrove disarankan menggunakan rasio jantan 6-7 dan betina 3-4 ekor/ kurungan.

\section{Ucapan Terima Kasih}

Tulisan ini merupakan bagian kegiatan penelitian Hibah Strategi Nasional "Pengembangan Teknologi Budidaya Kepiting Bakau (Scylla spp.). Pola 
Silvofishery Berbasis Masyarakat dan Berkelanjutan" tahun 2015. Penulis mengucapkan terima kasih kepada Kemenristek Dikti yang telah mendanai penelitian ini.

\section{Daftar Pustaka}

Changbo, Z., D. Shuanglin, W. Fang \& H. Guoqiang. 2004. Effects of $\mathrm{Na} / \mathrm{K}$ Ratio in Seawater on Growth and Energy Budget of juvenile Litopenaeus vannamei. Aquaculture, 234: 485496.

Cholik, F. 2005. Review of mud crab culture research in Indonesia. Central Research Institute for Fisheries, Slipi, Jakarta, Indonesia.

Christensen, S.M., D.J. Macintosh \& N.T. Phuong. 2005. Pond production of the mud crab Scylla paramamosain (Estampador) and S. olivacea (Herbst) in The Mekong Delta, Vietnam, using two different supplementary diets. Aqua. Res., 35: 1013-1024.

Karim, M.Y., H.Y. Azis, Muslimim \& A.M. Tahya. 2016. Nutrient Content of Body and Growth as Physiological Responses of Mud Crab Scylla olivacea Reared Male Monosex in Mangrove. IJ Pharmtech Resear. 9(6):336-338.

Karim, M.Y. 2013. Kepiting Bakau (Scylla spp.) Bioekologi, Budidaya, dan Pembenihannya. Penerbit Yarsif Watampone, Jakarta.

Lee, S.Y., J.H. Primavera, F. Dahdouh-Guebas, K. McKee, J.O. Bosire, S. Cannicci, K. Diele, F. Fromard, N. N. Koedam, C. Marchand, I. Mendelssohn, N. Mukherjee \& S. Record. 2014. Ecological role and services oftropical mangrove ecosystems: areassessment. Global Ecology and Biogeography, (GlobalEcol.Biogeogr.), 23:726-743

Mahato. 2008. A survey on performance of different feed for mud crab (Scylla serrata) fattening and hardening at Paikgacha, Khulna.Thesis. Magister Science in Aquaculture.Department of Aquaculture Bangladesh, Agrjcul Tural University, Mymensingh. (Unpublish).

Mirera, D.O. \& P. O. Moksnes. 2014. Comparative performance of wild juvenile mudcrab (Scylla serrata) indifferent culture systems in East Africa: effectofshelter, crab size and stocking density. Aquacult Int. DOI 10.1007/s104990149805-3. Springer International Publishing Switzerland.

Mirera, D.O. \& A. Mtile. 2009. A preliminary study on the responseof mangrove mud crab (Scylla serrata) to different feed types underdrive - in cage culture system. Journal of Ecology and Natural Environment Vol.1(1),pp.007-014.

Okpiliya, F.I., E.B. Effiong, E. Imoke \& I.Eja. 2013. Mangrove forest ecosystem utilization and depletion: implication for occupational changes In Calabar South, Nigeria. European Journal of Sustainable Development,2 (1):149-162.

Ong, J.E. \& W.K. Gong. 2013. Structure, Function and Management of Mangrove Ecosystems. ISME Mangrove Educational Book Series No.2. International Society for Mangrove Ecosystems (ISME), Okinawa, Japan, and International Tropical Timber Organization (ITTO), Yokohama, Japan.

Pedapoli, S. \& K.R. Ramudu. 2014. Effect of water quality parameters on growth and survivability of mud crab (Scylla tranquebarica) in grow out culture at Kakinada coast, Andhra Pradesh. International Journal of Fisheries and Aquatic Study, 2 (2): 163-166.

Peterson, B.D. \& D.L. Mann. 2011. Mud crab aquaculture, in recent advances and new species in aquaculture (eds R. K. Fotedar and B. Phillips) p. 115-135, Willey Blackwall, Oxford, UK.

Sagala, L.S.S., M. Idris \& M.N. Ibrahim. 2013. Perbandingan pertumbuhan kepiting bakau (Scylla serrata) jantan dan betina pada metode kurungan dasar. 2013. Jurnal Mina Laut Indonesia, 3: 46-54.

Shelley, C. 2008. Capture-based aquaculture of mud crab (Scylla spp.). Global overview. FAO Fisheries Technical Paper, No. 508. Rome, FAO. pp:255-269.

Shelley, C. \& A. Lovatelli. 2011. Mud crab aquaculture. A practical manual. Food and Agriculture Organization, Rome.

Steel, R.G.D. \& J.H. Torrie. 1993. Prinsip dan Prosedur Statistika. PT Gramedia Pustaka Utama Jakarta.

Sunarti, Y., R.D. Soejoedono, N.L.P.I. Mayasari \& A.M. Tahya. 2016. RNA expression of farnesoic acid O-methyltransferase in mandibular organ of intermolt and premolt mud crabs Scylla olivacea. AACL Bioflux. 9(2):270-275.

Tahya, A.M. 2016. Kajian organ mandibular dan pemanfaatannya sebagai stimulan molting kepiting bakau Scylla olivacea. Institut Pertanian Bogor. Bogor (ID). 76 hal.

Tahya, A.M., M. Zairin Jr., A. Boediono, I.M. 
Artika \& M.A. Suprayudi. 2016. Important role of mandibular organ in molting, growth, and survival of mud crab Scylla olivacea. IJ Chemtech Resear. 9(12): 529-533.

Tahya, A.M., M. Zairin Jr., A. Boediono, I.M. Artika \& M.A. Suprayudi. 2016. Expression of RNA encode FAMeT in mandibular organ of mud crabs Scylla olivacea. IJ Pharmtech Resear. 9(3):219-223.

Trino, A.T., O.M. Millamena \& C. P. Keenan. 2001.
Pond culture of mud crab Scylla serrata (Forsskal) fed formulated diet with vitamin and mineral supplements. Proceeding of the International Forum on the culture of portunoid crabs. Asian Fisheries Science, Asian Fisheries Society, Manila, Philippines,14(2001):191-200.

Wijaya, N.I., F. Yulianda, M. Boer \& S. Juwana. 2010. Biologi populasi kepiting bakau (Scylla serrata F.) di habitat mangrove Taman Nasional Kutai Kabupaten Kutai Timur. Oseanologi dan Limnologi di Indonesia 36(3): 439-456. 